\title{
Az ősz, az ősz: A közelitö tél mint beszédesemény és mint szövegváltozat
}

\author{
(egy módszertani olvasat, következményekkel)*
}

„Behunyom szemem, ott leszek talán Ahol együttt vártok rám. Ma is elhiszem, hogy visszavár Ujra az a régi nyár!" (Venus: Régi nyár)

\section{A módszerröl}

A Debreceni Egyetem magyar szakán tartott klasszikus magyar irodalmi „korszakszemináriumok" egyik alapelve úgy alakítani a tematikát, hogy abban jelentős mértékben jelenjenek meg a középiskolában is tanítandó transzparens szövegek. A mindenkori közoktatásbeli szöveggyüitemény (illetve a párhuzamos egyetemi előadáshoz tartozó vizsga alapkövetelménye) tehát az a bázis, amely irányt mutat, mit beszéljünk át, mit olvassunk újra ezeken a kurzusokon. Immár jó pár éve tartó ezirányú közös munkálkodásom a szeminaristáimmal kitermelt egy-két újszerünek és produktívnak vélt alternatív értelmezési javaslatot, amelyeknek igen jó a teljesítőképessége a hallgatók körében, módszertanilag is. ${ }^{1}$

A közös elemzés menete, mely az évek során kristályosodott ki, már bejáratott metódusnak tekinthetö. Elöször úgy olvassuk az éppen aktuális költeményt, hogy ujjunkkal (képletesen, de akár konkrétan is) letakarjuk a verstestet megelőző szerző nevét, illetve az azt lezáró keletkezési évszámot. Ezt követően felfedjük az évszámot; majd, a harmadik elemzési körben, a szerzői nevet is. Ezek az interpretációs körök világosan utalnak bizonyos irodalomolvasási paradigmákra, melyek konkretizálása bizonyára minden szakembernél kicsit másképpen nézne ki. Nálam, hermeneutikai alapokon bár, de leginkább az immár hosszú évekkel ezelőtt lezajlott ún. kontextualista-, vagy Mi, filológusok-vita kiválóan tanítható (s több szempontból is valóban kifejezetten tanulságos) anyagának fényében ${ }^{2}$ a következőképpen.

\footnotetext{
* A dolgozat megírását a Debreceni Egyetem EFOP-3.4.3-16-2016-00021 pályázata tette lehetővé.

${ }^{1}$ Az egyik ilyenről már beszámoltam korábban Vörösmarty Mihály verse kapcsán: A vén cigány kiegészitéseinek kiegészitése, Alföld Online, 2017. december 23. http://alfoldonline.hu/2017/12/a-ven-ciganykiegesziteseinek-kiegeszitese/ (Letöltés ideje: 2019. december 22.)

2 TAKÁts József, Nyolc érv az elsödleges kontextus mellett, ItK, 2001/3-4, 316-324; SÁRI László, Érvek az „utolsó kontextus” mellett, ItK, 2003/1, 96-111; ТАКÁTs József, Az irodalomtörténet-írással kapcsolatos
} 
A radikálisan kitakaró kezdeti olvasásmód bármiféle jelentés(re)konstrukció „utolsó kontextusát" helyezi előtérbe, illetve egyfajta nem-kontextualista retorikai poétikakezelést müködtet. Vagyis tulajdonképpen azt tudatosítja, hogy minden egyes olvasás a hermeneutikailag meghatározott befogadói pozícióból ered, annak összefüggésrendszere a müveleti forrása. Ilyenkor hangsúlyozottan az éppen aktív (különleges) tudat találkozik az adott (általános) szöveggel, legyen is ennek a tudatnak bármiféle háttérismerete avagy világlátása. Ennek az olvasásmódnak akkor is tudni kell kezdeni valamit a müvel, ha a szerző, a keletkezés korszaka nem ismeretes. Mindez nem jelenti azonban azt, hogy nyakló nélkül aktualizálgatunk vagy pszichologizálgatunk, hanem a szöveg saját logikájára (egy régi szép kifejezéssel: játékszabály-horizontjára), illetve azokra a szövegjelenségekre figyelünk, amelyek minden specifikusabb felkészültség nélkül mindig feltérképezhetők: prosopopeia, aposztrophé, vershelyzet, beszédhelyzet, retorikaigrammatikai alakítástechnika, intertextualitás. Jellemző a magyar közoktatásra még mindig, hogy erről a típusú olvasói hozzáállásról kell a legtöbbet beszélni a szemináriumokon, mert nem áll hozott tudásként rendelkezésre. Egyfajta, a hagyományos középiskolai beidegződéseket szándék szerint felfüggesztő szoros olvasás jegyében mindig azt kérem az adott szeminárium fiatal kollégáitól ennek kapcsán, hogy próbáljanak a versszövegre valamiféle nem mindennapi beszédeseményként tekinteni. Ne keressék rögtön a rendszerint jól ismert író (Csokonai, Vörösmarty, Petőfi, Berzsenyi, Kölcsey) védjegyeit a versszakokban, hanem hagyják az éppen velük találkozó nyelvet hatni, megszemélyesülni. ${ }^{3}$ A verset megvalósító hangot próbálják úgy kötni egy közel sem egyértelműen adott beszélőhöz, hogy annak személyessége ne egy eleve feltételezett tudat megnyilvánulásaként tételeződjön, hanem mint e beszéd által a szemük előtt körvonalazódó alakzat. ${ }^{4} \mathrm{Az}$ a líraesemény, ami egy odaadó, érdemi olvasás során végbemegy, sohasem egyvágányú, de lehetséges kimenetei soha nem is szóródnak a végtelenbe.

\footnotetext{
meggyöződéseimröl, ItK, 2003/6, 729-741; SzILAsı László, „Nem ma”: Az irodalom külügyeitől való ideiglenes tartózkodásom okairól (Válasz Takáts Józsefnek), ItK, 2003/6, 742-755; TAKáTs József, Válasz Szilasi László „Nem ma” címü írására, ItK, 2003/6, 756-759; DÁvidHÁzi Péter, Mi, filológusok, és a bizonyosság vágya (Pozitivista kötődéseink egy szakmai vita fényében), ItK, 2004/1, 3-55. A vitához lásd még: http:// magyar-irodalom.elte.hu/arianna/filologia/index.html (Letöltés ideje: 2019. december 22.)

${ }^{3}$ Ez persze lehetetlen kihívás (bár törekedni azért lehet a gyakorlására), hiszen valóban jól ismert, a közoktatásban akár többszörösen is feldolgozott művekről van szó, melyek kapcsán éppen azok az adatszerü vagy frázisos háttérismeretek élnek élénken a hallgatók emlékezetében, amelyeket egy időre ki kellene kapcsolni ahhoz, hogy más, de alapvető értelemösszefüggéseket pillanthassanak meg. - Ehhez hasonló mủelemző problémákról bővebben: MolNÁr Gábor Tamás, Mit jelent a megértés történetisége? (Egy Zrínyi-epigramma példája), Alföld, 2012/3, 92-96.

${ }^{4}$ Vö. „A személyiség nem kifejeződik - a kifejezés az, ami valamiképp mindig megszemélyesül. [...] A személyességet nem egy feltételezett tudat megnyilvánulásaként tételezhetjük, hanem az olvasóban megképződő beszéd termeli ki mint hatást." (LAPIs József, Enyhe mámor: A legújabb líra kihívásai az ezredforduló után, Alföld, 2009/12, 81.) Ezek a mondatok nem a klasszikus magyar irodalom korszakának költészetéhez füződő líraolvasás kapcsán születtek meg, de azt gondolom, arra is érvényesek. Hasonló érvényüek, mint ahogy Culler fogalmaz az aposztrophéval kapcsolatban: „lehetséges lenne ezt az alakzatot magával a lírával azonosítani”. Jonathan Culler, Aposztrophé, ford. SzÉLEs Csongor, Helikon, 2000/3, 372.
} 
Ami leginkább szabályt ad egy, a mindennapi nyelvhasználathoz képest mindig normaszegő szépirodalmi beszédnek, az a megszólalásnak, a hangnak az a berendezett és kikutatható világa, amelyben teljesít. Ilyen paraméter e beszéd szituativitása, jelenetezése, díszletezése, kronotopikussága, kommunikációs megoldásai, maszkolási, párbeszédképző stratégiái. Az efféle szövegtípusoknak az a közismert tulajdonsága, hogy bennük mindig bizonyos szintü teatralitás van: a hanghoz arc társul, amely fiktív perszónaként alakoskodik, maszkol, tehát voltaképpen mindig valamilyennek mutatkozó álarc (prozópon). Ez a dramatizált „beszélő arc” mindig fordul valakihez, mindig viszonyra lép egy szubjektumként kezelt másikkal (dologgal vagy személlyel), az olvasó számára ugyanakkor mindig adott a lehetőség, hogy mindezt kikémlelje, kihallgassa egy aposztrophé-háromszög részeként. Vagyis adott a lehetőség végigkövetni azt, hogy az eleve textuális versbéli személy miként válik karakteressé, élővé. Miként közeledik hozzánk, felöltöztetve, fazonírozva (fashioning) önmagát a nyelv, a vershelyzet színházában, többek között azáltal, hogy miként beszél, miben áll nála a figurativitás, milyennek láttatja magát, és hogy kihez intézi igencsak keresett szavait.

Egy vers ugyanakkor mindig történeti képződmény is egyben. A szöveg temporalitását a korszakindexet, vagyis a keletkezési évszámot felmutató második kör tárja fel. Ez jár utána „az elsődleges kontextus” (itt hermeneutikai maximákkal egyeztetett) perspektívájának, mely a szöveg eredeti körülményeire kíváncsi, a lehetséges mértékig és igényességig visszahelyezkedve azokba. Finomhangolja a szöveg beszédmódjainak, retorikai fogásainak beágyazottságát, pontosítja és újrapozicionálja a szókészlet jelentésrétegeit, felülvizsgálja az első olvasat asszociációit, versbeszélőről alkotott elképzeléseit. Egyáltalán, tudatosítja, hogy a mü, amivel dolga van, nem csupán egy személy alkotása, hanem személytelen, illetve személyközi rendszerek összjátékának eredménye; olyan köztes közeg, amely különféle alakítástechnikák találkozási pontján mozog, és folyamatosan változtatja önmaga megértésének feltételeit az időben. ${ }^{5}$

A szerzői nevet felfedő utolsó fázis aztán már könnyedebb, sematikusabb terep, mivel otthonos rendet visz a témába (például elhelyezi a verset az írói pályaképben), és aktivizálja a megelőző tanulmányokból amúgy is ismerősebb referenciális tézismondatokat az életrajzi adatösszefüggéseket illetően. Jobb esetben ugyanakkor - a megelőző körök fényében - problematikussá, rövidre zárttá, naivvá és művivé is válhat ennek a szintnek a jó része, legalábbis lelepleződnek életrajzi következtetései közül a súlytalanok és semmitmondóak; az adott költőszemély átlagostól eltérő nagyságát kultikusan firtató helyzetmondatokról nem is beszélve. Ezt a távlatot az órákon mi jellemzően arra használjuk fel, hogy segítségével az illető szerző költészetének adott irányvonalát belehelyezzük röviden a korabeli hazai, illetve európai tendenciákba, vagy kiemeljük evokatív, illetve más szövegek megmintázásában tevékeny hatástörténeti jelentőségét. Miközben ezeket az interpretációs köröket rovom a szeminaristákkal - amelyek átérhetnek egymásba -, természetesen folyamatosan

${ }^{5}$ Lásd BorbéLy Szilárd, A Vanitatum vanitas szövegvilágáról, Fehérgyarmat, Kölcsey Társaság, 1995, 13. 
ismertetek fontosnak ítélt szakirodalmi álláspontokat, illetve emlékeztetek ilyenekre, melyek közül egyeseket üdvözlünk, másokkal vitába szállunk. A metodológia természetéből fakadóan kevesebb ilyen pont van az első szakaszban, ahol tényleg az önállóság, az autonóm dialogicitás kialakítása a cél, $s$ több a második, különösen a harmadik etapban.

A közelítő tél (A'Közelitő Tél) címü Berzsenyi-költemény e tanulmányban lejegyzett értelmezése az elözőekben vázolt müveletsor szellemében artikulálódott csoportosan, melynek kilencven perces szemináriumi dinamikáját nehezen tudja leképezni írott szakszöveg. A maga korlátozott módján azonban képes számot adni róla, s szólni az ezen olvasási gyakorlat nyomán felvetődő irodalomtanítási anomáliákról is.

\section{Csak mi és a szöveg}

A (lírai) perszóna egy kigondolt és megmunkált közegben képződik meg A közelítő télben, s egy jellegzetesen egységes, jólformált szubjektumképlet rajzolódik ki a szöveg egyszólamúságában. A Lolliját emlegető férfi művelt ember: egyszerre több diszkurzív regisztert mozgat, súlya van annak, amit mond, összetett és gazdag a szókészlete, veretes a stílusa. Idéz, a klasszikus Horatiust visszhangozza, mondandójának egyik legfőbb viszonyítási pontja és mintája egyértelműen az antik hagyomány. Ez a müvelt férfi „ligetünk"-ről beszél, mi-alakzatban. Attól a pillanattól lehetünk részesei ennek a (nyelvi) eseménynek, hogy a férfi ráveti szemét a tájra. Nem deríthető ki pontosan, kihez fordul oda, az azonban bizonyos, hogy egyre kevésbé érdekli a Másik, magának (és magáról) beszél. Az ő koszorújáról, az ő tavaszáról, az ő koráról, az ő behunyt szeméről. A legjellemzőbb szemináriumi feloldása a vershelyzetnek, hogy a beszélő már a kezdet kezdetétől önmagához intézi szavait, tulajdonképpen monologizál. Egyfajta belső magánbeszéd ez, a másik tehát legalább olyan kvázi-partner csupán, mint a szöveg mindenkori (ki)hallgatója. A szöveg inkább gondolat itt, tulajdonképpen belülre szól, erőteljes auto-aposztrophéban. A jelenetkeretet leginkább úgy szoktuk elképzelni az órán, hogy a férfi egy ablakból nézi a tájat - az ablak általában is igen jól keretező, hálás médium -, hátratett kézzel mereng (kontemplál), lassan, csendesen. Nincsen kint abban a térben, amit szuggesztív szavaival lefest, tablószerü egységében is látja a tájat, melyen végigpásztázza tekintetét, vagyis perspektivikus távolság áll rendelkezésére, ugyanakkor annyira mégis közel van mindehhez, hogy lássa a részleteket, a hulló levelek szintjéig. A látvány, amit a férfi közöl, nem cosa mentale, nem elözetesen rögzített és determinált kép, nem gépies pictura. ${ }^{6}$ Gondja

\footnotetext{
${ }^{6}$ Nem „lelki táj”, miként az az elemzésekben sürűn előbukkan, mert nincs okunk feltételezni, hogy ne volna reáliaként felfogható. Vagyis kérdéses az a nézet, hogy „az alany nem egy empirikus természeti térben áll, hanem a szemléletében megformált, szubjektív értelmű tájban”. (BÉcsy Ágnes, Berzsenyi Dániel: A közelítő tél = Irodalomtanítás a harmadik évezredben, szerk. Sipos Lajos, Bp., Krónika Nova, 2006, 441.) A dolog, úgy tetszik, éppen fordítva van: a feltáruló táj fogja a szemléletet, a szemlélő gondolatait formálni.
} 
van arra, hogy autonóm tekintete kameraszerüen követhető legyen: fentről lefelé (1. vsz.), fentről lefelé (2. vsz.), majd távolra (3. vsz.), kitágítva a teret a hegyekig, hogy utána újra fókuszáljon, a lankák szőlőtöveire (a bíbor thyrsusokra). Mindezt oly módon teszi, hogy az órákon ezen a példán keresztül szoktam figyelmeztetni a nyelv egyedülálló kettős performatív teljesítményére, miszerint az egyszerre tud energikus - vagyis konkrét materialitásával, hangzósságával, lüktetésével érzéki élményt okozó, fület gyönyörködtető -, illetve enargikus - plasztikus, kifejező, a színek, illatok, hanghatások, textúrák érzeteit szimulatíve létrehozó, szavakkal illuzionisztikus ingerületekké transzformáló - lenni. Az időmértékes verselés, az 'o, 'l' és 'r' hangok összjátéka (vö. energeia), illetve az öt érzékszerv liget-leírásban végbemenő lehengerlése a búgó madárhangtól a lengedező szellőn át az illatozó, színes völgyig (vö. enargeia) szakirodalmi közhelyek - de hogy mi is ez a liget, az már kevésbé egyértelmü.

Hogy a tájleírás itt „negatív festés”, azt mindig elmondja az ember, vagyis hogy itt a terület éppen hiányaiban jelenül meg, ám ez nem mindig szokott meggyőzőnek bizonyulni az órákon. Inkább tudnak azonosulni a hallgatók azzal az ennél egyszerübb lehetőséggel, hogy a felékesített táj a beszélő számára nem jelenik meg, csupán tudja, hogy ilyen volt; csupán híradást kapunk róla, s az olvasóban is csupán felvillannak ezek a nagyon intenzivált, performatív effektusok (madárdal, csermely-csobogás, szüreti mulatság), de valójában egy sivár őszi táj a valós tapasztalat.7 Tartósan egy ilyet látunk, melyet a beszélő is néz, elmélkedőn, mélán. Ez a táj pedig nem olyan, mint ő, hanem ez a táj ő maga. Táj és férfi egy, ráadásul abban a stadialitásban is, amilyen a táj egykor volt (amilyen a férfi most) és amilyenné lett (amilyenné a férfi egészen biztosan válni fog). A beszélő önmagát látja meg, az ablak voltaképpen tükör. Nem metaforikusan utal az őszi liget erre a férfiúra, hanem én-allegóriaként identikusan jelenti őt. Az egyszerre szédítően kitáguló, majd ugyanolyan szédítő sebességgel egy kis virágra fókuszáló intertextuális aforizma ebből a felismerésből fakad fel. S ettől a ponttól nem tudjuk osztani a szakirodalom szintén sztenderdnek mondható azon álláspontját sem, hogy itt végig egy sztoikus bölcs rezignáltságával állunk szemben, ${ }^{8}$ mert a beszéd az 'Oh' indulatszótól kezdődően egzaltálttá válik, a kezdeti szemlélődő, lassú, elgondolkodó hangnem ezzel keveredik; a contemplatio elöször a meditatio (4. vsz.), majd pedig a lamentatio retorikájába vált át, mely ívet a vers kitartott elégikus színezete is alátámasztja. A textualizált én diszkurzív pályája a kesergés, a siralom tónusában alakul tovább, a megelőző színezettel

\footnotetext{
${ }^{7}$ Ekkor tehát megkérdőjeleződnek az ilyesfajta álláspontok: „[A]z idilli liget nem pusztán emlékképként, de létező realitásként is jelen van a beszélő számára.” VADERNA Gábor, A legszebb tizenkettő: Berzsenyi Dániel A’ közelítő Tél címü versének újabb olvasatairól, Irodalomismeret, 2014/1, 80.

${ }^{8}$ Többek között Csetri beszél „férfiasan visszafogott líráról” (CsETri Lajos, Berzsenyi Dániel A közelítő tél címü versének elötörténetéhez = Cs. L., Amathus: Válogatott tanulmányok, szerk. SzAJBÉLy Mihály, ZeNTAI Mária, Bp., L'Harmattan, 2007, II, 114.), de Bécsy Ágnes is így fogalmaz: „Nyelvi modalitás tekintetében a vers szövege tüntetően egysíkú: kijelentő.” (BÉcsY, i. m., 438.) Vö. még: „Érzelgősségnek, siránkozásnak nyoma sincs a versben: a költő panasza a bölcs, sztoikus férfi hangján szólal meg[.]” (Név nélküli kortárs elemzés. http://verselemzes.hu/berzsenyi-kozelito-tel-verselemzes/5/ (Letöltés ideje: 2019. december 22.)
} 
hektikusan váltakozva (a kijelentő és felkiáltó mondatmóduszok egymásra felelgető összjátékában is, melyről hajlamosak elfeledkezni a különféle interpretációk, mondván, hogy ez egy jellemzően egymodalitású, fegyelmezett szövegmü).

Az első körös olvasatnak csak ezzel a szövegverzióval van dolga, melynek értelemképző centruma a 'közelítő' tél címbeli konceptusa. A tél, mely ott ólálkodik már a lefestett őszi tájban is, közhelyes mitopoétikával utal a halálra, melyen még a szerelem sem segít, mely a férfi siralmainak éppen eléggé indokolt oka, hiszen mi lehet drámaibb ennél a távlatnál? A halál „torokszorító félelme” pedig, ha már össze kell gyüjteni szövegbeli utaltjait, ott van a hervadásban, a táj kihaltságában, a szárnyas időben, az enyészetben, az elvirító koszorúban, a becsukott szemben.

Ezen a ponton érdemes átkapcsolni azonban a második fázisra, amikor tehát beengedjük a történeti dimenziót a szövegértelmezésbe, $s$ arra is kíváncsiak vagyunk most már, hogy miként müködhetett, mit mondhatott a szöveg keletkezésének jelenében. Itt tehát már bővebb és speciálisabb műveltségbeli háttértudás szükséges, melyek közül a szempontunkból legfontosabb a megelőző, „asztalfióknak” írt szövegváltozat kérdése (köztudottan: $A z$ ősz címü), mely a szerző minden ráhatástól, diskurzuspolitikától és tekintélyalapú hatalmi relációtól mentes eredetije. Merthogy az általunk eddig elemzett, és az iskolákban kizárólagosan tanított szövegváltozat tudhatóan egy „második szerzo”” (Kazinczy Ferenc) hatására készült átirat. Az eredeti pedig éppen ezért nem ugyanolyan - sokkal koherensebben, problémamentesebben és megejtőbben beszél valami másról, mint a halál.

\section{Számok $(1804,16+)$}

A vers a 19. század legelején, 1804 körül keletkezett. Közismert, hogy Kazinczy 1808as kritikai megjegyzéseinek hatására Berzsenyi változtat a szövegén, így lesz 'barna' csalétból 'durva, 'nectár' thyrsusból 'bíbor', 'hervadozó' bimbóból 'elvirító, Bartsi kökényszeméből pedig Lolli szemöldöke, mert amaz „nem illik ódába”. ${ }^{10}$ És nem mellesleg győz a Kazinczy-féle címadás: „Nem Ösz, hanem közelítő tél.” ${ }^{11}$ Tulajdonképpen lehetetlen az átdolgozott változatot illető prekoncepciók nélkül rátekinteni az autentikus Berzsenyi-verzióra - olyan ez, mint megfilmesítés után olvasni egy könyvet -, az órán mi mégis megpróbáljuk. Ebben a szövegtérben pedig sehol nincsen tél, ahogy a megelőzőnél is csupán a cím sugallta. És nincsen halál sem, mert nem arról szól. Nem elmúlás van benne, hanem múlás, de az meglehetős radikalitással. ${ }^{12}$

\footnotetext{
${ }^{9}$ Vö. VADAI István, Távolodó nyár: Berzsenyi Dániel: A’ Közelítő Tél című verséről, Tiszatáj, 2006/12, 9.

${ }^{10}$ Kazinczy Berzsenyinek, 1808. december 23., KazLev. VI. 162., 1389. sz. (KazLev = KazInCzy Ferenc levelezése, I-XXI, kiad. VÁczy János, Bp., 1890-1911.)

${ }^{11}$ Uo.

${ }^{12}$ Hasonlóan a „Már nem vered a feleséged?” culleri példamondatának eseményszerű erejéhez, e kérdés előfeltevésrendjének mellbevágó megrázkódtatásához. Vö. CuLLER, i. m., 376.
} 
A megjelenített táj, amely a szemünk előtt bontakozik ki ezen a kivételes, egyszerre energikus és enargikus nyelven, nem a közelítő tél tere; jóval több köze van a pompázatos és lüktető tavaszhoz, illetve - mint azt az e dolgozatot leginkább ösztönző Vadai István kiemeli - a „távolodó” nyárhoz. ${ }^{13} \mathrm{~A}$ tavasz-későnyár érzéki kontinuuma (a zefír tavaszt hozó meleg fuvallata, a búgó gerlice, a tavaszkor virágzó erdei viola, majd az egyre csak érő szőlőszemek és az aranyősz szüreti mulatsága) ugyanakkor nincsen már jelen ebben a tájban, amely voltaképpen a beszélő személyazonossága. Amikor a 'szomorun kihalt' látványról van szó, ${ }^{14}$ az mindazonáltal nem azt jelenti, hogy a természet halott, hanem hogy elhagyatott, sivár, üres, kiveszett belőle a tavasz és a nyár élettelisége. A szárnyas idő végzete sem a halál ebben a szövegben, a kis nefelejcs által szimbolizált mindenség ugyanis 'enyész'. Az enyészet fogalma pedig - amelyet a Berzsenyi-szakirodalom egyöntetűen kiemel, de leginkább, mint Bécsy Ágnes ${ }^{15}$, a „semmivé tesz", vagyis tulajdonképpen az elpusztulás kontextusában - ezt is jelenti: lassú szétesés és bomlás, tovatünés. Vagyis nem kell itt halálnak lennie ahhoz, hogy a helyzet drámai legyen, hiszen a krízis annak felismerésében is állhat, hogy lassan, de biztosan elfogyunk, elenyészünk, napról napra, fokról fokra, minden egyes élőlény totalitásában. ${ }^{16}$

A halál végezetül nincsen ott az utolsó elemzői mentsvárban, a 'béhunyt szem'-ben sem, pedig ennek feloldásában is egyöntetü a szakirodalom. ${ }^{17}$ Nincsen olyan szótár ugyanis (MÉKSz, MNytSz, TESz, Cz-F., Mnyelvúj.Sz, MTsz, ÚMTsz stb.), amelyik ne hozná hamarabb a behuny igének a képzelődés, fantáziálás, álmodozás köré vonható jelentéstartományát, mintsem a halálét. A mai napig úgy fogalmazunk egyébként is inkább, ha valakinek a halálát eufemizáljuk, hogy „örökre lehunyta szemét”. Amiről itt szó van, arról Petőfi beszél nagyon kifejezően: „Testi szemeimet / Behunyom, és lelkem szemeivel nézek." ${ }^{18}$ Vagyis itt a behunyt szem nem egy halott metonímiája, ${ }^{19}$ hanem a koncentrált emlékezésnek, az intenzivált benső jelenvalóvátételnek, vagyis az imaginárius vágybeteljesítés igyekezetének a jelölöje. A vágy itt azonban nem teljesedik be, mert még a szerető Bartsi varázslatosan nagy, barna, kerek (kökény) szeme sem „igézheti fel” ezt a férfiút. A 'fel nem igézheti' szekvencia pedig nem azt jelenti, hogy „megigéző erejével fel nem idézheti, vagyis támaszthatja” ${ }^{20}$, tehát nem halottak revitalizálásáról van szó, ${ }^{21}$ hanem

\footnotetext{
${ }^{13}$ VADAI, i. m., 9.

${ }^{14}$ Az első verziót Vadai István szövegközlése nyomán idézem: Uo., 10.

${ }^{15}$ BÉCSY, i. m., 440.

${ }^{16}$ Vadai István is ebben a kontextusban (ti. mulandóság) emeli ki az enyészet szó szerepét. (Vö. VADAI, $i$. m., 4.)

${ }^{17}$ BÉCsy, i. m., 437-438, de még Vadai is. VAdAI, i. m., 9.

${ }^{18}$ PetőFi Sándor, Kis-Kunság = PeTőFi Sándor Összes költeményei, Magyar Elektronikus Könyvtár. http:// mek.oszk.hu/01000/01006/html/vs184804.htm (Letöltés ideje: 2019. december 22.)

${ }^{19}$ Vö. BÉCSY, i. m., 438.

${ }^{20}$ Uo., 437.

${ }^{21}$ Mint például a Barátomhoz című, valószínűsíthetően közel azonos időben keletkező másik Berzsenyiversben, ahol ugyanakkor egyértelmüen 'felidéz' alak szerepel: „Elmarad tölünk szeretett barátnénk, / Itt hagyunk mindent, valamit szerettünk, / Semmi nem kísér szomorú koporsónk / Néma ölébe. // A piros
} 
- mint a szótári jelentések, s Vadai is egyértelműen kifejti ${ }^{22}$ - a bűvöletről, az elbájoltságról. A könnyebbség kedvéért megint csak Petőfivel: „Én beléptem, ő rámnézett, / Aligha meg nem igézett!"23 Vagyis úgy fordítható köznapi prózára a zárórész, hogy még ábrándos emlékezéseimben sem válik valódi vágyakozássá mindaz, amit a szerelmem jelentett - minden édességével együtt sem izgat már fel.

A szövegmű egyre inkább kitárulkozó alakja nem azért kesereg, mert meg fog halni, nem ezt látja meg a tájban. Hanem azt, hogy „,repül az idő”: hogy odahagyja, s vissza se tér majd 'gyönyörü' kora. Elhagyja a fiatalság tavasza, de a férfikor nyara is, pedig még ki sem használta az időt igazán, még alig kezdődött el a 'zsenge virágok'-ban kódolt igazi, nektárdús, tartalmas élet. ${ }^{24} \mathrm{~S}$ bár mindez még itt van, miért gondolható, hogy nem túl távoli az az idő, amikor végérvényesen őszi tájjá változik? Mert tulajdonképpen (vö. enyészet) mindez már történik: 'Lassanként koszorúm' bimbaja elvirít.' Pontosabban, hogy az eredetit idézzük: 'Lassanként koszorum bimbaja hervadoz.'

Közhely, hogy a koszorú a hírnév, a dicsőség, a földi glória jelképe, vagy - mint Bécsy Ágnes mondja e vers kapcsán - a felkentség, elismertség ősi jelvénye. ${ }^{25}$ Ebben a versben azonban egyértelmüsége ellenére problematikus, mert nem igazán van helyi értelme itt ennek a motívumnak, maximum úgy, ha egy isteneknek tetsző mindenkori sikeres, dicső élet, vagy egyfajta elvont életerő jelentéstartományában értjük. ${ }^{26}$ Ám ha végiggondoljuk, hogy ezt a férfit „zsenge virágokat” illető „szép tavaszának”,

hajnal derülő sugára, / A barátságnak kegyes ápolási, / A legesdeklőbb szerelem siralmi / Fel nem idéznek!" Berzsenyi Dániel, Barátomhoz = Berzsenyi Dániel Összes versei, Magyar Elektronikus Könyvtár. http:// mek.oszk.hu/00600/00614/html/vers03.htm (Letöltés ideje: 2019. december 22.)

${ }^{22}$ VADAI, i. m., 7.

${ }^{23}$ PetöFi Sándor, Befordúltam a konyhára... = PeTőFI, i. $m$. Ebben az esetben a dolog éppen ellentétes azzal, amit Vaderna mond: „a behunyt szemet nem lehet elbájolni”. VADERNA, i. m., 79.

${ }^{24}$ Csetri Lajos alapvető értelmezésében az elmúlásnak még csak a sejtelme ütötte meg a költőt, „gyönyörü kora” még nagyon is itt van, szép tavasza nektárját még csak most ízleli ajaka, zsenge virágait még alig kezdte el illetni. (CsETri, i. m., 114.) Egyetérthetünk abban, hogy egyfajta beteljesült eszményi kor a versjelen, melyben a lírai én megérzi ennek mulandóságát, de semmi nem utal arra, hogy ez még csak most kezdődött volna el; a 'még alig' annyit jelent, hogy túl keveset ahhoz képest, amilyen közel jár az ősz (mert 'lassanként' itt van). Többek között ezért sem indokolt támogatni az ún. ideale Gegenwart, az „eszményi jelenvalóság” számos értelmező által hangoztatott koncepcióját (BÉCsY, i. m., 442; VADERNA, i. m., 80; CsETRI, i. m., 112.), amely újabb „túlolvasásként” tünik fel. Ez a léthelyzet/vershelyzet éppen nem az ideális jelenlét - még úgy sem, ha arra fektetjük a hangsúlyt, hogy negatíve jelenik meg -, hiszen a táj felvillanásaiban, emlékfoszlányaiban idillikus csupán, valójában hervadó és üres, a beszélőt pedig nem a harmónia ünneplése boldogítja, hanem az ősz hirtelen tudatosuló antropológiai gondja keseríti. Sokkal inkább látszik akkor már idevonatkoztathatónak Horváth János teóriája a „regényes önszemléletről”, amennyiben itt is egy szituációt látunk magunk előtt - noha itt elsősorban nem az emlékezését -, s ily módon az (el)beszélés „mostja” „tágul ki” elöttünk. Vö. SzILÁGyi Márton, VAdERna Gábor, A klasszikus magyar irodalom = Magyar irodalom, föszerk. GinTLI Tibor, Bp., Akadémiai, 2010, 351.

${ }^{25}$ BÉCSY, i. m., 437.

${ }^{26}$ Ha szerzői-biográfiai perspektívából olvasunk, vagyis ha Berzsenyi a költő szól, akkor is bajos művészi dicsőségről, babérkoszorús halhatatlanságról beszélni egy 1804 körüli versnél, amikor a dunántúli földesúr még csak az asztalfióknak írja költeményeit. 
„gyönyörü korának” folyamatos elenyészése zaklatja, ${ }^{27}$ mely lassan de annál biztosabban oda vezet, hogy még legkedvesebb szeretöjének ábrándos emléke sem „igézheti” többé fel, az illető sor (is) egészen más értelmet nyer. S ezzel benne vagyunk e tanulmány, illetve a szemináriumi elemzés közepében.

A mindenki által jól ismert, átírt változatban az a bizonyos „koszorú-bimbó” lassan elvirít. Az most mellékes, hogy a hétköznapi normállogikát tekintve e változtatás nagy mellélövés, hiszen kizárólag élő virág tud elvirítani (cselekvő ige), koszorún díszlő nemigen, de nem ez a fontos, a líralogika egyébként is csodákra képes. Az elgondolkodtatóbb itt és most az, hogy az eredeti változatban a koszorú bimbaja egyre csak hervadozik, egy grammatikailag passzív igeszínezetü, folyamatos igeszemléletü, tartós-huzamos igejellegű szerkezetben, amelynek ilyeténképpen (is) az a fö jellemzője, hogy kitartottan történik, folyamatosan, hosszasan megy végbe (vö. enyészet), nem úgy, mint a jóval aktívabb 'elvirít' alak esetén, amelynek mozzanatosbefejezett igeisége sokkal jobban is rímel a halál radikális pontszerűségére. Az első verzióban tehát „hervadozunk”, mégpedig egy olyan versben, ahol az antropológiai küszöbhelyzetet nem annak drámája adja, hogy meghalunk, hanem egyáltalán, hogy addig is egyre csak öregszünk. Hogy a vágy végül már nem lesz elevenítő, csupán archiváló jellegü. Hogy nem lesznek többé leszakajtható zsenge virágok. Az áthallások mögött egy koherens vonatkoztatási mező húzódik meg, amiről általában még mindig kínos beszélni a mi iskolakultúránkban, s jellemzően virágnyelven szoktunk róla számot adni.

Az órán emlékeztethetünk arra, hogy a koszorú egyik alapjelentése (a korszakban is) csupán annyi, hogy karikafüzér, kördísz. Vagy utánanézhetünk, milyen kontextusokban jelenik meg a korabeli populáris kultúrában a bimbó motívuma. Amikor ennyire kiélezzük a témát a versszöveg által nem mellesleg markánsan kijelölt irányba, amikor újra összefoglaljuk, hogy e líra alanyának gondja itt az, hogy egy időszak visszavonhatatlanul bekövetkezö, végérvényes végével kell rövidesen szembenéznie, melyben testi-lelki szemeit nem fogja felvillanyozni többé már semmi sem, s melyben állandósul a kérdés, hogy „Hol van az a régi nyár?”, akkor sokan már csalfán pislognak az órákon arra a kérdésre, hogy mit is jelent itt ez a szólam: 'koszorúm bimbaja hervadoz' - hiszen ekkor már zavarba ejtően jól látják a képet. Amely azt mutatja (Berzsenyit evokáló, bár szintén csalfa választékossággal), hogy Priaposz ennél a férfinél nem áll éppen jól. Ekkor, ebben a hermeneutikai nyomkövetésben már egészen világos, hogy e sor olvasható a hím genitália egyes anatómiai képleteinek megnevezéseként, illetve annak leginkább a korral járó élettani-pszichés diszfunkciójaként. Ennek a réme a testi-lelki öregség, az ősz, mely az első változat címe is volt. Ekkor pedig - csakúgy, mint az illető korszakszemináriumok dekonstruktív példamondatában: „Vak tyúk is talál szemet.”

\footnotetext{
${ }^{27}$ Itt jegyzendő meg újra, hogy ez az olvasat a „gyönyörű kor” feloldását nem a költő (Berzsenyi) felől érkező kommunikáció részeként érti, s nem hisz abban, hogy az Ámor és a Múzsák együttes ereje által ihletett lélek állapota lenne ez a „gyönyörü kor”. (CSETRI, i. m., 113.) A gyönyörü kor itt egészen egyszerüen életkori stádiumot jelent, amelyet az antik tradíció az akmé fogalmával ír le (fénykor, virágkor).
} 
(na de szemgolyót vagy gabonaszemet?) - nem egy szubjektum, sokkal inkább maga a nyelv beszél. Benne pedig eldönthetetlenül, vagy éppen párhuzamosan müködő a poliszemikus jelentéspár: az ősz mint évszakallegória, illetve az ősz(ülő) ember. Bárhogyan is van, a versbeszéd pillanatában még nem ösz hajú férfiú nem szimulálja, amit mond; nem „eirón”, mondott és gondolt között nincsen nála különbség, sőt éppen hogy a maga módján felettébb szókimondó, kíméletlenül őszinte pontosság jellemzi. Ez a férfi dokumentátor: saját testi érzékleteinek, lelki érzéseinek dokumentálója, melyet hol csendesebb, hol hangosabb monologikus beszédként visz színre.

Nem szeretnék a túlolvasás olyan hibáiba esni ezeken az órákon (sem), melybe a bon mot szerint azok a pszichoanalitikus olvasatok, amelyek a müvekben minden fekvő dolgot női, minden állót férfi nemi szervnek látnak, mégsem szoktam letorkollni az ezen a szinten olykor-olykor jellemzően már megtáltosodó hallgatók azon gondolatfutamait, miszerint nem véletlenül finomít a 'Nectár thyrsusokon' is Berzsenyi, bíborrá téve azokat. Mert bizony e szőlőtövek sem egyszerű szőlőtövek, hanem a mámor istenének, Dionüszosznak fenyőtobozban végződő - ráadásul itt isteni nedűvel telt - botjaként fallikus utalások, mely megfigyelés kontextusán belül az sem véletlen, hogy a 'nectár' jelölő az eredetiben kétszer fordul elö, másodjára egyértelműen a „tavaszias” élet gyönyöreinek hívószavaként. Nyilván nem feltételezzük ezeket intencionális olvasatoknak, s nyilván ésszerű keretet kell adni minden egyes interpretációnak, de ha levezethetö, védhető, számot kell vele vetni. Ráadásul itt a szövegmü belső líralogikája és a történeti (rekonstruktív) olvasásmód egyaránt lehetővé teszi ezeket az értelmezői irányvonalakat, melyek fényében még az sem mellékes, hogy a hervad igével kezdődik ennek a lassanként „hervadozó” figurának a mondandója. Ítéletünk szerint ezek az összefüggések még mindig jobban védhetők, mint az egyébként kiváló szakemberek efféle eszmefuttatásai a verstestben egyszerűen meg nem jelenülő téllel kapcsolatban: „A közelítés mint poétikai kerülőút arra enged következtetni, hogy A közelitő tél egészen egyszerüen az élet dicsérete, és azért hiányzik belőle a tél, mert a magyar verstradícióban sem idegen szimbolikája szerint ez az évszak már a nem-élet ideje."28

Berzsenyi e költeményét, föként annak eredetijét lehet egyfajta (szexuál)gerontológiai távlatban olvasni, mert nem a halál van benne - amit mindig belevetítünk kazinczyánus hevülettel -, hanem az enyészet így is éppen eléggé fajsúlyos testi-lelki drámája. ${ }^{29}$ A vanitatum vanitas, a theatrum mundi, vagyis a 'minden csak jelenés' élménye, az elkeseredés, a lamentáció szövegbeli foka éppen eléggé indokolt egy ilyen kontextusban is. Ráadásul ekkor még az az értékítélet is megkockáztatható a művet illetően, hogy bár halál-versként tisztes helyet foglal el a magyar szépirodalom élmezőnyében, öregedés-versként egyenesen párját ritkítja.

\footnotetext{
${ }^{28}$ Faragó Kornélia, A közelítő (Berzsenyi Dániel: A közelítő tél) = A közelítő tél, szerk. FűzFA Balázs, Szombathely, Savaria University Press, 2012, 201.

${ }^{29}$ Vagy amivel a leginkább egyet lehet érteni, ha már mindenképpen a halál volumenével akarunk dolgozni: „S ez az élmény a halált nem mint elgondolható jövendőt tartalmazza, hanem mint örökös jelent, [...]." (BÉCSY, i. m., 443.)
} 
Bár Csetri Lajossal láthatóan több ponton nem értünk egyet, az a megfigyelése kiemelkedően fontos számunkra, hogy a szövegmüben voltaképpen kétféle táj jelenik meg, „egymásba úsztatva”. ${ }^{30} \mathrm{Az}$ egyik az antikizáló, és a szemináriumokon jellemzöen sorban lefordítandó szókészlet (labyrinth, Zephyr, symphonia, thyrsus) emelkedett, „fentebb” reprezentációjában, a másik a saját, vernakuláris nyelvváltozat hétköznapi dunántúliságában épül ki (tarlott, gerlice, csalét, gerezd). ${ }^{31}$ Ezek összjátéka az első változatban kiegyenlítettebb, leginkább az utolsó sor következtében ('Bartsim barna kökényszeme'), mely a 'Lollim barna szemöldöke' második verziójánál sokkal keresetlenebb és ismerősebb még ma is, ha máshonnan nem, hát Kukorica Jancsi kökényszemủ Iluskájára emlékeztetve. Az első verzióban több a kapcsolóelem, a hervadás (Hervad már ligetünk - koszorum bimbaja hervadoz), a barnaság (barna csalét - barna kökényszeme), illetve a nektár metafora (Nectár thyrsusain - Nectárját ajakam) momentumaiban, amelyek egymásra felelnek a „kontempláló” és „lamentáló” szövegrészekben. Többek között ezek egységesítik a verstestet, a tagadó móduszok hálószerüen kiterített megoldásával egyetemben, kompakttá téve a verskompozíciót. Az első verzió is ódikus, de mintha sokkal hangsúlyosabban közelítene az óda-hagyomány carmenvonulataihoz: jóval dalszerübb, közvetlenebb, letisztultabb. ${ }^{32}$ Ennek a keresetlenségnek sincsen azonban kisebb drámaisága, hiszen benne van többek között a versközepi „meditáció" nem éppen elitkulturális és fennkölt (enyésző) nefelejcse, az igaz szerelem és az örök hűség szimbolikus kis virága, mely igencsak beszédes. Már csak nevében, annak imperatívuszában is (Ne felejts!). Főként, ha összekapcsoljuk a zárlat képével, az odaadó emlékezőt performáló „béhunyt szem” általunk ajánlott értelmezésével. Mindez pedig megejtően népdalszerü is egyszersmind. Ehhez az utóbbi összefüggéshez azonban már indokolt bevezetni a szerzői nevet is.

\section{Nevek (B. D., Bartsi, Czenczi, Lolli)}

Most, hogy már a 'Berzsenyi Dániel' név is látszik a vers elött, szabadabban kezelhetjük az irodalomtörténeti címkéket. A 'Lassanként koszorum bimbaja hervadoz' iménti olvasata nem éppen egy neoklasszicista elégiko-óda illetékességi köre, bár így is gyönyörü, hiszen valóságos műalkotásként állnak elö benne az elsődleges nemi jelleg szomatikus markerei, melyek mint „díszek” „hullanak”. Ennél a változatnál ugyanakkor

\footnotetext{
${ }^{30}$ Erről bővebben: VADAI, i. m., 8.

${ }^{31}$ A szótárak és a szakirodalom viszonylatában van némi ellentmondás a tekintetben, hogy a költemény nem antik diszkurzív rétegét illetően mely szavak tájnyelviek, régiesek, hétköznapiak, s melyek nyelvújításiak, választékosak, eszményítők (vö. 'csalét', 'csermely', 'gerlice'). A szótárak szerint az első, Bécsy Ágnesnél hangsúlyozottan az utóbbiak aránya nagyobb (vö. Bécsy, i. m., 437.), ám ő is kiemeli a költemény grammatikai megoldásainak tájnyelvi dominanciáját.

${ }^{32}$ Ezt a különbséget a szakirodalom széles körüen hangsúlyozza is: VADERNA, i. m., 81; VADAI, i. m., 8-11; CSETRI, i. m., 114.
} 
nem lép közbe Lolli barna szemöldöke, hogy végérvényesen megemelje a diskurzust, itt a jóval földhözragadtabb Borbála néz ránk kökényszemeivel. Ezen utóbbi, eredeti verzió rendre veszít a szakmai utóéletben a másik valóban füleket „igézö” dallamvezetése, illetve a szemöldök-motívumban az Erósz-himnuszok szintjére emelt költői dikció ellenében, amelyről például Bécsy Ágnes értekezik ihletett szépséggel. ${ }^{33} \mathrm{Az}$ most kevésbé fontos, hogy ez a szemöldök volt már barokk, volt már petrarkista müveltségnyom, ${ }^{34}$ világokat kormányzó jupiteri attribútum, ${ }^{35}$ sőt a minden irónia nélküli órai kedvencünk, egy sírdombot formázó (egyben a halott férfit szimbolizáló) „grafikusan” közlékeny testrész is. ${ }^{36} \mathrm{~A}$ lényeges az, hogy klasszicizálóbbá, választékosabbá teszi ugyan a költeményt, ugyanakkor a másik átíráshoz, a koszorún élő virágként elvirító bimbóhoz hasonlóan a képzavar határát súrolja, és személytelenebbé, elvontabbá válik tőle a vers. ${ }^{37}$ A személyesség, az individuális líra Berzsenyit illető fontossága ${ }^{38}$ pedig nemcsak az első változatban kifejezettebb, de általában a népköltészetben, közköltészetben is az.

Legutóbb Vaderna Gábor fejtette ki korszakmonográfiájában, hogy elitkultúra (müköltészet), folklorikus kultúra (népköltészet) és populáris kultúra (közköltészet) között egyáltalán nincsen olyan éles különbség a korszakban, mint ahogy azt mi utólag hiszszük. ${ }^{39} \mathrm{~A}$ népköltészettel egészen könnyedén összekeverhető - $\mathrm{s}$ a korban is gyakran összekevert - közköltészettel a neoklasszicista érzékenység magasirodalmát az antropológiai horizont, az intenzíven megélt érzelmek egyéni kifejezésének távlata füzi egybe, ez kanalizálja leginkább a dalkultúra különböző (a nagy- és a kishagyományban egyaránt kódolt) regisztereit is. E paraszti-népi és nemesi-közköltészeti kultúra ráadásul újra és újra visszacsatolódik a társadalmi elit világába: a lírai köznyelvben az alanyi dalköltészet válik a 19. század egyik legfontosabb lírai formájává. ${ }^{40}$

Valami olyasféle összefüggés látszik itt körvonalazódni, ami kikezdi az eddigi, Berzsenyit is érintő irodalomtörténeti sémákat. Közismerten sokat foglalkozik ugyanis a Berzsenyi-szakirodalom annak eldöntésével, hogy a klasszikus vagy a romantikus

\footnotetext{
${ }^{33}$ BÉCsY, i. m., 443-444. Vö. még: „[Az első változat utolsó sora] az elégikus hangnemű vers végére valóban stílustörést hozott, de a végleges szöveg nagyszerü stílusérzékről tanúskodó javításával az Eroszhimnuszok szintjére emelte Berzsenyi." (CsETRI, i. m., 114.)

${ }^{34}$ Bővebben ezekröl: VADERNA, i. m., 78-79.

${ }^{35}$ CSETRI, i. m., 114; BÉCSY, i. m., 438.

${ }^{36}$ Vö. http://verselemzes.hu/berzsenyi-kozelito-tel-verselemzes/6/. (Letöltés ideje: 2019. december 22.) Figyelemre méltó, hogy „kiégett” férfiként beszél a név nélküli elemző a behunyt szemü lírai énről.

${ }^{37}$ Vö. VAdAI, i. m., 11.

${ }^{38}$ Vö. BÉCSY, i. m., 436.

${ }^{39}$ VADERNA Gábor, A költészet születése: A magyarországi költészet társadalomtörténete a 19. század első évtizedeiben, Bp., Universitas, 2017, 58-65.

${ }^{40} \mathrm{Vö.} \mathrm{„[A]} \mathrm{19.} \mathrm{századi} \mathrm{költészet} \mathrm{éppen} \mathrm{a} \mathrm{közköltészettől} \mathrm{veszi} \mathrm{át} \mathrm{egyik} \mathrm{legfontosabb} \mathrm{témáját} \mathrm{és} \mathrm{az} \mathrm{azzal} \mathrm{járó}$ poétikai és létszemléletet. A költészet különböző hagyományai között éppen a közköltészet volt az, amely évszázadokon keresztül igen nagy teret engedett a szubjektivitásnak: a szerelmi dalok, a gúnyolódó versek, a mulattatók értelemszerüen emberi érzésekről számolnak be. Ahogy a 19. században a modernizálódó (elit) líra szubjektivizálódik, úgy szorul háttérbe a szubjektivitás mellé szerzői autoritást még nem rendelő közköltészeti hagyomány." Uo., 64-65.
} 
kis-episztémé világába utalja-e a kemenesaljai Mestert, esetleg éppen abban lássa jelentőségét, hogy e két korszak határának, az ún. hermeneutikai korszakküszöbnek a reprezentánsa. ${ }^{41}$ Akárhogyan is van, ami Berzsenyiben „romantikus” (például a szubjektum és az időbevetettség nagy traumája), az - e versben legalábbis - megelőzi még a klasszikából romantikába átmenetet is, és markánsan szülőföldi, „alapnyelvi” poézis. Vagy ha úgy tetszik (anya)nyelvközösségi, a népköltészet és a közköltészet e tanulmányban tovább nem pontosítandó nagy elegyeként. Vagyis Berzsenyi tulajdonképpen nem előbb klasszicista, mint romantikus - már ha van értelme egyáltalán ennek a dilemmának -, de még az is lehet, hogy a dolog egyenesen fordítva van, mely sejtést $A z$ ősz/A közelitő tél című szövegpáros igencsak alátámasztja. A rózsa, a búgó gerlice, a viola, a nefelejcs, a bimbó, a kökényszem mind megtalálható motívum abban a folklórban, lírai popularitásban, amely Berzsenyi saját somogyi anyanyelvét is konstituálta, $\mathrm{s}$ amely lexémákat minden további nélkül alkalmazza az olyan veretes müfajokban is, mint az óda. Voltaképpen a romantika poétikáját, programját műveli a kezdetektől, tökéletesen reflektálatlanul, egész egyszerüen saját vernakuláris kultúráját használva. ${ }^{42}$ Nosztrifikálja Horatiust, egyik legfontosabb magyar applikálójává válik, de e magával hozott kultúra kontextusán belül. A nyelvi regiszterek keveredése jórészt emiatt lesz olyan sajátosan egyedi nála, mint elemzett versében is.

A reflexió szintjén ugyanakkor az antik beszédhagyomány, mint legfontosabb elsajátított idegennyelve, láthatóan a legfontosabb számára. Emiatt lesz a klasszicista Kazinczy lelkes híve, „sugallatára” jócskán átdolgozván $A z$ ösz címü versét is, s emiatt vallja azt, hogy a 'nektár' szóban az egész hellén mitológia képzetköre benne van, amit meg kell tudnunk látni benne. ${ }^{43}$ Mindezek fényében a verset illető női nevek egyenesen poétikatörténeti jelölőknek tekinthetők: Bartsi a közköltészeti/népköltészeti paradigmának, a Kazinczy által alternatívául felkínált Czenczi a klasszicizmus fennkölt és elemelt normatív poétikai paradigmájának, s e helyett végül a Lolli alak mint az előbbi kettőt kontamináló, s a korszakban nem is olyan ritka harmadik lehetőségnek a címkéje. E női nevektől függetlenül a vers továbbra is olvasható úgy mindenesetre, amiképpen beszéltünk róla: öregedés-versként, a maga módján merőben szókimondó panaszdalként, sorsénekként, fiatalság-siratóként. Olyan szövegként, melynek közköltészeti/népköltészeti visszhangjai ott vannak a különböző vénember-csúfolókban, életkor-gúnyolókban, boszszantó rímekben, keservekben, sőt még Csokonai Dorottyájának vénlány-paródiájában

\footnotetext{
${ }^{41}$ Vö. ehhez árnyaltabban: VAderna, A legszebb tizenkettö, i. m., 77.

${ }^{42}$ Legalábbis a romantika ernyőfogalmának azt a változatát, amit például a Grimm testvérek neve - Magyarországon pedig leginkább Kölcsey hagyományközösségi gondolkodása - jelent. Vö. S. VARGA Pál, A nemzeti költészet csarnokai: A nemzeti irodalom fogalmi rendszerei a 19. századi magyar irodalomtörténeti gondolkodásban, Bp., Balassi, 2005, 131-140, 426-440.

${ }^{43}$ Berzsenyi Dániel, „Észrevételek Kölcsey Recensiójára” = Berzsenyi Dániel Prózai munkái, kiad. FóRIzs Gergely, Bp., EditioPrinceps, 2011, 138. Erről bővebben: S. VArga Pál, Berzsenyi - Arany - Horác: A klasszikus örökség nosztrifikálásának útjai a romantika elött és után $=A z$ ismeretlen klasszikus: Berzsenyitanulmányok, szerk. FóRIzs Gergely, VADERnA Gábor, Bp., reciti, 2018, 145.
} 
is. ${ }^{44}$ Ráadásul egy ilyen távlatban világosan látszik, hogy Berzsenyi „közköltészetileg” és „klasszikailag” egyaránt jól tudhatta, mit jelent a sikamlós témákat játékosan kezelö, avagy esztétikailag megemelő képes beszéd, vagy ha úgy tetszik, a „virágének-logika”.

Csetri Bíró Ferenc nyomán nyomatékosítja, hogy Berzsenyi számára az egyszeri lét válik értékké, $s$ a személyes élet időbeli fenyegetettsége a negatív alapélmény, ${ }^{45}$ individuális lírájának ezért középpontja a mulandóság életérzése, a szakirodalmi konszenzus szerint is. Valóban történik itt egy nagy váltás a neosztoikus-keresztény emberfelfogáshoz képest, hiszen ennek a versnek a Berzsenyije nem igazán hisz a napról napra gyarapodó emberi bölcsesség, a „szép öregség” képzetében, egy másik élet ígéretére várva, mint például a Fohászkodás címü versében. Ez a melankolikus(!) beszélő igen konkrét veszteségként érzékel minden múló napot az enyészet bizonyosságától elborzadva, mely fokról fokra következik be a többértelmü aranykor után. Hasonlóan kíméletlen perspektíva ez, mint a vénember-csúfolók, vagy akár a férfiasság-siratók, verses életkori panaszok sokszor igen vaskos világa, vagyis az időbe vetett szubjektum drámája nemcsak az ún. „romantika” ügye, hanem jellegzetesen benne van az azt megelőző alacsony-irodalomban is. De - egészen máshonnan érkezve - ilyen irányultságú az antikvitás korabeli recepciójának embereszménye is, melyben az egyik legfontosabb érték az Apollón-szobor kapcsán éppen az, hogy örökifú (időtlen). ${ }^{46}$ Vagyis egy olyan idealizáció, mint amilyen az eszményi természet korabeli elképzelése is - ebből az aranyállapotból esik ki a beszélő, legyen a cím $A z$ ősz vagy akár $A$ közelitő tél.

Az illető szövegmű szinkron (1804 körüli) intratextusainak rövid exponálása jön még jól az órákon. Adódik rögtön a Barátomhoz című költemény ezekből az évekből, amely ugyanazon életérzéssel foglalkozik, ám még koncentráltabban „vernakuláris”, mint a koszorúval körülvett hervadozó bimbó ${ }^{47} \mathrm{~A}$ Levéltöredék barátnémhoz, melyben Kazinczy korrekciója előtt szintén jellemzően több volt a somogyi tájszó, s melyben ott van a mi egész koncepciónk az 'elestvéledtem' páratlanul kifejező hapaxában, szintén fontos testvérszöveg. A tüz, a láng, a szikra motívuma evidens érvénnyel szervezi a kompozíciót, melyet csodaszépen rövidre lehet zárni átvitt értelmű alakzatként, amenynyiben Berzsenyi költői lelkének tüzéről van itt szó, a fennkölt ihletettség allegóriájaként. De hát persze a 'tüzemet gerjesztem' sor tulajdonképpen a pipa szeleltetéséről szól, $\mathrm{s}$ a 'kanóc pislogó lángja' is az, ami, minden felesleges virágnyelv-áthallás nélkül... Ami viszont tényleg meggondolandó, hogy a vers második fele szinte ugyanazt az emlékező férfit viszi színre, mint e tanulmány elemzett költeményének utolsó versszaka, akinél

\footnotetext{
${ }^{44} \mathrm{Az}$ életkorral kapcsolatos panaszdalokra, keservekre bővebb példa: Közköltészet 3/B. Közerkölcs és egyéni sors. Régi Magyar Költők Tára XVIII., szerk. CsöRsz Rumen István, KüLlős Imola, Bp., Universitas, 2015. Híres még: Pajkos énekek, szerk. SToLl Béla, Bp., Szépirodalmi, 1984.

${ }^{45}$ CSETRI, i. m., 111.

${ }^{46}$ Vö. RADNóTi Sándor, Jöjj és láss! A modern müvészetfogalom keletkezése - Winckelmann és a következmények, Bp., Atlantisz, 2010.

${ }^{47}$ Vö. „[A virágkor m]elly rövid s kedves! valamint az első / Éjjelünk, mellyen szeretőnk ölében / Életünk legszebb örömébe égve / Kóstola szívünk.” (BERZsenyi Dániel, Barátomhoz, i. m.)
} 
a szerelem jobb híján már ugyanúgy csupán szelíd, hamvadó szikra, hangulata pedig nem kevésbé melankolikus. Ami a két szöveg között végezetül feltünően hasonlóan müködik még, az a képiség, a látvány elsődlegessége, amennyiben $A$ közelitő télre is igaznak véljük azt, amit Vaderna ír a Levéltöredékről: „olvasható egy olyan poétikai kísérletként, mely az ént képként akarja elbeszélni, illetve egy látványt akar átfordítani a lírai közlés nyelvére." 48

Minden ilyen szemináriumon megfogalmazódik a kérdés, hogy a körülbelül harminc éves Berzsenyit valóban foglalkoztathatta-e annak drámája, hogy lassanként már nem fogják nagy barna kökényszemek tágítani pupilláit. A kérdést jellemzően jobban implikálja az eredeti, személyesebb és keresetlenebb versváltozat, ahol nem éppen a „szellemi nemzö” Erószról szól a történet az ő szemöldökével. Beszédes, ahogy Csetri ír a dilemmáról, miszerint a "hatalmas szerelmes” Berzsenyiről alig tudunk valamit, legfeljebb „sejtelmeink” lehetnek róla. Vallomásai lehetnek mítoszteremtők, lehetnek igazak, „de valószínü, hogy nem az az éterien vágyakozó szerelmes volt, amilyennek a dalai mutatják”. ${ }^{49} A z$ ösz előbbiekben bemutatott értelmezése éppen nem egy „éteri” szerelmest tételez - itt a szerelem nagyon is testi természetü. Csetri szerint Berzsenyi ideális szerelmes költő, szentimentális epedéssel, a német polgári dalköltészet gyengéd és eszményi érzéseivel..$^{50}$ Nos, szerintünk, legalábbis ennek a költeménynek az eredetijében, éppen annyira közköltészeti és reális, mint amennyire polgári és ideális. $S$ ne feledjük mindehhez a fóleg szempontunkból kihagyhatatlan, jól ismert és sokat idézett - harmincöt évesen éppen Kazinczynak írt - önreprezentációt sem: „Én eggy korúim között legelső magyar tánczos voltam, lovat, embert, asztalt által ugrani nékem játék volt. Sopronyban magam tizenkét németeket megvertem és azokat a’ város' tavába hánytam, és az én első szeretőm az én karjaim között elalélt." ${ }^{\prime 1}$ Itt aztán nyilván bele lehetne kapaszkodni az utolsó tagmondatba, s ennek kapcsán kiélezni a „hervadozás” versbéli helyi értékét, vagyis annak tragédiáját, hogy ez a vad dunántúli férfiú, ez a pesti finom literátorok között is csak cigányzenét hallgató szilaj magyar eztán már soha többé nem lesz olyan „kemény legény”. Ehelyett ráirányítanám a figyelmet a levélrészlet folytatására: „Én már mast formalis öreg vagyok”. ${ }^{2}$

\section{Szerintem}

Bevallom, nehezen tudom úgy tanítani ezt a verset, hogy ne süssön rólam, mennyire rontottnak érzem a Kazinczy-féle változatot (nyilván a hallgatóknak kellene ítélkezni). Azét a Kazinczyét, akit a szakemberek elnéző mosolyú bevett véleményével szemben

\footnotetext{
${ }^{48}$ Szilágyi, Vaderna, i. m., 352.

${ }^{49}$ CSETRI, i. m., 113.

${ }^{50}$ Uo.

${ }^{51}$ Berzsenyi Kazinczynak, 1811. március 13., KazLev. VIII. 393., 1961. sz.

${ }^{52} \mathrm{Uo}$.
} 
egyáltalán nem tartok rossz költőnek, hanem korabeli (klasszicista) tehetségnek, de ez egy másik téma. Valamiféle fennkölt elvontság szellemében Kazinczy nem kívánhatott kevesebbet a halál nagy emblémájánál, amit beleolvasott a költeménybe, mert elvétette azokat a téteket, amelyek nem voltak ismerősek számára sem poétikailag, sem egzisztenciálisan. Valamiféle normatív stilisztikai választékosság jegyében számon kérte a somogyi dialektus (számára) szokatlan grammatikája mellett többek között a „szóismétléseket", Berzsenyi pedig meghajolt, ezáltal egy dekoratívabb, megmunkáltabb szövegmüvet kaptunk, az intimitásában legbátrabb szövegmomentumok (kökényszem, hervadozás) kiiktatásával. Hatásvadász sarkítással: Kazinczy „rárontott” és „elrontotta” ezt a költeményt - bár meglehet, hogy olvasatommal én is „megrontom” azt (a végsőkig kihasználva az egész témát körüllebegő fülledt áthallásokat).

Mindenesetre úgy gondolom, sok szempontból produktív ez az értelmezés, hiszen kérdéseket, problémákat, konzekvenciákat ösztönöz. Például azt, hogy e münél tekintetbe kell venni a szövegváltozatokat, még a középiskolában is. Ennek kapcsán pedig osztályközösségtől függően fel lehet villantani a genetikus szövegkiadás fontos alapelvét, mely szerint nincsen felettes szövegváltozata egyetlen irodalmi münek sem, hanem az tulajdonképpen mindig fellelhető változatainak összessége, amelyeket egyenrangúakként kell kezelni, transzformációik összjátékára figyelve. ${ }^{53}$

Mindaz, ami a közoktatás irodalmi szöveggyüjteményeiben benne van egy-egy korszakot illetően, az csupán a jéghegy csúcsa. Ám miként Ady korai költészete nem érthető például az adott évek városi folklórjának, slágereinek ismerete nélkül, úgy a kisebb századforduló világa sem érthető igazán a tömegkulturalitás legalább részleges órai felvillantása nélkül, mely jóval többször fontos kontextusa egy-egy ismert szövegnek vagy költészetnek - például a János vitéznek, illetve Petőfi írásmüvészeténe ${ }^{54}$ - mint azt gondolnánk. Vagyis a tanításba sokkal több „közköltészet” kellene, a kultúratudományos fordulat popkultúrát rehabilitáló attitüdjével összhangban.

Ugyanígy fájón hiányzik a hasonló olvasatok bátorsága a hivatalos oktatási elvárásrendből. Hiszen nemcsak meghatódni lehet az iskolában a költészettől, mondjuk a folyton folyvást visszatérő hazaszeretet jegyében, hanem például humort és derüt is lehet tőle tanulni, illetve beszélni az élet kamaszokat amúgy is mélyen érdeklő olyan alaptényezőiről, mint a testiség, erotika, szexualitás, amelyeket jellemzően csak nagyon óvatosan szoktunk érinteni, ${ }^{55}$ de amely dimenzió nélkül nemcsak Berzsenyi

\footnotetext{
${ }^{53}$ Ennek legújabb magyar tudományos továbbgondolásáról és textológiai alkalmazásáról lásd Berzsenyi Dániel Levelezése. Elektronikus Kritikai Kiadás, szerk. Debreczeni Attila, s. a. r. Fórizs Gergely, 2017. http://deba.unideb.hu/deba/berzsenyi/fogalmak.php (Letöltés ideje: 2019. december 22.)

${ }^{54}$ Vö. Csörsz Rumen István, Pönögei Kis Pál, avagy Petöfi és a közköltészet = Ki vagyok én? Nem mondom meg...: Tanulmányok Petőfiről, szerk. Szılágyi Márton, Bp., Petőfi Irodalmi Múzeum, 2014, 203-226; Bognár Péter, $A$ János vitéz közköltészeti forrásai: a hazugságmesék = Doromb: Közköltészeti tanulmányok 2., szerk. Csörsz Rumen István, Bp., reciti, 2013, 231-240.

${ }^{55}$ A nyelvi tabuizálás máig ható nyomai, még a „progresszívebb” kutatóknál is, az efféle megfogalmazások: „olykor bizony trágár szerelmi dalok”, „olykor bizony szókimondó versek”. VADERNA, A költészet születése, i. m., 60, 61. (kiemelés tölem) Weöres Sándor Psychéjének többek között azért kellene a középiskolában fontosabbnak lennie, mert ennek a dimenziónak a feldolgozásában is zseniális.
} 
érthető kevésbé, hanem például Móricz Zsigmond egész életműve is. A komolykodó és prüd magyar oktatási rendszer, a tankönyvek tulajdonképpen ugyanazt csinálják az illető Berzsenyi-verssel, mint Kazinczy: elitizálják és patetizálják. Ám talán nem kell mindig leborulni egy-egy írásmü előtt, hanem inkább megtanítani, mi is az a „Hymen sorompója”, vagy hogy mit is jelent igazából a hosszú éveken át gondosan őrzött, s a házassággal egyszerre csak felnyíló „tulipános láda”. A közköltészetnek, a népi folklórnak is nagyon sokszor azon jár az esze, mint e versnek - mint az olvasónak. Ez pedig nem valamiféle deviancia vagy öncélú tabudöntögetés, hanem megértendő és kiismerendő antropológia. Többek között ez az (ön)ismeret az, a „Lányomnak mondom, menyem is értse!" aposztrophé-szerkezete, ${ }^{56}$ amivel közösen szembesülhetünk, ha $A$ közelítö telet előzményével együtt tanítjuk.

\title{
Bodrogi Ferenc Máté \\ egyetemi adjunktus \\ DE Magyar Irodalom- és Kultúratudományi Intézet \\ bodrogi.ferenc@arts.unideb.hu
}

The Autumn, the Autumn: Dániel Berzsenyi’s "A Közelítö Tél” ("As Winter Approaches”)

as Speech Act and as Reading

(a Methodological Interpretation with Consequences)

\begin{abstract}
This paper, after introducing a group-based method of a university poetry-analysis, presents a noteworthy seminar-interpretation of Daniel Berzsenyi's poem with the title 'A közelítő tél' ("As Winter Approaches"). The point is that the work is not read as a poem of death, but as a poem of aging, and the first version of the history of its morphosis (with the title 'Az ösz, “The Autumn”) is highlighted, in contrast to the final transcript, which is actually known only. It is obvious from the naturally non-exclusive interpretation that the poem - and Berzsenyi's entire poetry - has much more to do with the popularity of community poetry than we usually think, and the stakes of that poem, in the light of our reading, are quite different from what we have learned and thought so far. All of this also has a significant message for contemporary literary education.
\end{abstract}

Keywords: Dániel Berzsenyi, Ferenc Kazinczy, community poetry, reading, popularity, aging DOI: $10.37415 /$ studia/2019/3-4/103-119.

Open Access: Creative Commons Attribution 4.0 International (CC BY 4.0)

${ }^{56}$ Vö. Gellénné KöRÖzsı Eszter, Aposztrophé = Alakzatlexikon, föszerk. SzathmáRI István, Bp., Tinta, 2008, 122. 